PNL-2735

UC-70

\title{
Liquid-Fed Ceramic Melter: A General Description Report
}

\author{
J. L. Buelt \\ C. C. Chapman
}

October 1978

Prepared for the U.S. Department of Energy under Contract EY-76-C-06-1830

Pacific Northwest Laboratory Operated for the U.S. Department of Energy by Battelle Memorial Institute 


\title{
NOTICE
}

This report was prepared as an account of work sponsored by the United States Government. Neither the United States nor the Department of Energy, nor any of their employees, nor any of their contractors, subcontractors, or their employees, makes any warranty, express or implied, or assumes any legal liability or responsibility for the accuracy, completeness or usefulness of any information, apparatus, product or process disclosed, or represents that its use would not infringe privately owned rights.

The views, opinions and conclusions contained in this report are those of the contractor and do not necessarily represent those of the United States Government or the United States Department of Energy.

\author{
PACIFIC NORTHWEST LABORATORY \\ operated by \\ BATTELLE \\ for the \\ UNITED STATES DEPARTMENT OF ENERGY \\ Under Contract EY-76-C-06-1830
}

\author{
Printed in the United States of America \\ Available from \\ National Technical Information Service \\ United States Department of Commerce \\ 5285 Port Royal Road \\ Springfield, Virginia 22151
}

Price: Printed Copy $\$$

$\therefore$ Microfiche $\$ 3.00$

$\begin{array}{cc}\text {-Pages } & \text { NTIS } \\ & \text { Selling Price } \\ 001-025 & \$ 4.00 \\ 026-050 & \$ 4.50 \\ 051-075 & \$ 5.25 \\ 076-100 & \$ 6.00 \\ 101-125 & \$ 6.50 \\ 126-150 & \$ 7.25 \\ 151-175 & \$ 8.00 \\ 176-200 & \$ 9.00 \\ 201-225 & \$ 9.25 \\ 226-250 & \$ 9.50 \\ 251-275 & \$ 10.75 \\ 276-300 & \$ 11.00\end{array}$




\author{
J. L. Buelt \\ C. C. Chapman
}

October 1978

Prepared for

the U.S Department of Energy under Contract EY-76-C-06-1830

Pacific Northwest Laboratory Richland, Washington 99352 
.

.

. 
The Pacific Northwest Laboratory is conducting several research and development programs for the solidification of high-level wastes. The liquid-fed ceramic melter (LFCM) is a major component in the solidification process. This melter can solidify liquid highlevel waste, as well as melt calcined waste with glass additives and then solidify the mixture. This report describes the LFCM system and shows the main features of the refractories, electrodes and power systems, melter box and lid, draining system, feeding system, and off-gas system. 


\section{CONTENTS}

\begin{tabular}{|c|c|c|c|c|c|c|c|c|c|c|c|c|c|c|}
\hline SUMMARY • & - & • & - & • & - & • & - & • & • & • & - & $\cdot$ & 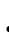 & \\
\hline INTRODUCTION & - & - & - & - & • & • & • & $\cdot$ & . & $\cdot$ & - & • & 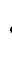 & \\
\hline HI STORY & - & - & • & - & . & • & • & • & • & • & • & • & 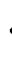 & \\
\hline DESIGN FEATURE & & - & . & - & • & - & • & • & • & • & - & • & 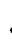 & \\
\hline REFRACTORY & & • & • & • & - & • & • & $\cdot$ & • & $\cdot$ & - & • & 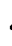 & \\
\hline ELECTRODES & $S$ AND & POW & $R S$ & TEM & - & • & - & $\cdot$ & - & • & - & • & 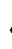 & \\
\hline CONTAINMEN & NT BOY & & • & . & • & . & . & $\cdot$ & • & $\cdot$ & - & - & 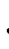 & \\
\hline PRIMARY DR & RIN & CONTH & & . & • & - & - & $\cdot$ & • & - & • & • & 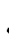 & \\
\hline BOTTOM DRA & & - & . & - & - & - & • & $\cdot$ & • & $\cdot$ & - & • & 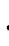 & \\
\hline AUXILIARY & HEAT I & ING & YST & & • & - & • & $\cdot$ & $\cdot$ & • & - & • & . & \\
\hline INSTRUMENT & TATION & & - & • & - & • & - & • & • & - & - & • & 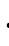 & \\
\hline FEED SYSTE & & - & - & - & • & • & • & • & - & • & • & • & , & \\
\hline OFF-GAS SY & ISTEM & - & • & - & • & • & • & $\cdot$ & • & $\bullet$ & - & $\bullet$ & & \\
\hline CONCLUSIONS & - & . & - & - & • & • & • & . & • & $\cdot$ & • & • & & \\
\hline
\end{tabular}




\section{LIST OF FIGURES}

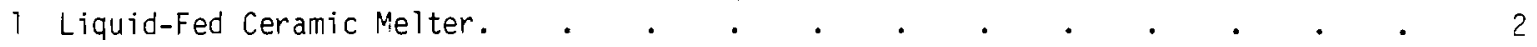

2 Glass Contact Refractory, Southeast View. . . . . . . . . . . 5

3 Glass Contact Refractory, Northwest View. . . . . . . . . . $\quad$. 5

4 Backup and Insulating Refractories .

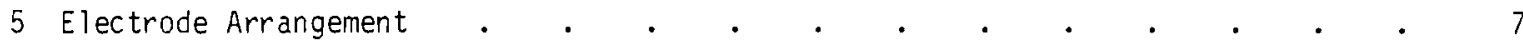

6 Liquid-Fed Melter Electrode Power Control Systems . . . . . . . . . $\quad$. 7

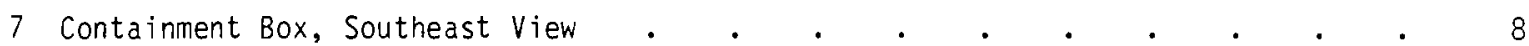

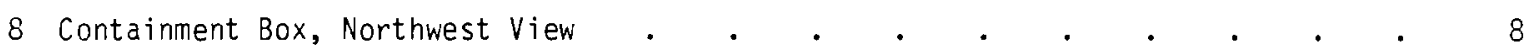

9 Screw Jack and Tilting Cradle . . . . . . . . . . . . . . . . . . 9

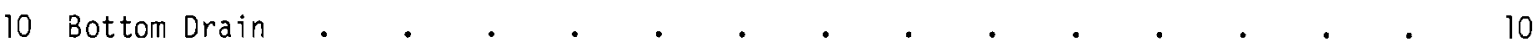

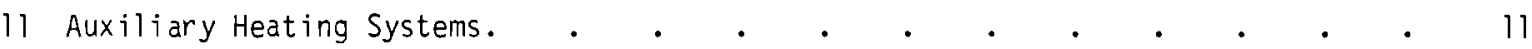

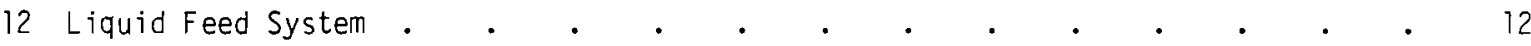

13 Off-Gas Treatment System • 
LIQUID-FED CERAMIC MELTER: A GENERAL DESCRIPTION REPORT

\section{INTRODUCTION}

The Pacific Northwest Laboratory (PNL), operated by Battelle Memorial Institute, is conducting a study for the Department of Energy (DOE) to develop suitable processes for incorporating radioactive waste into a glass. Such a process requires a reliable system that converts the aqueous liquid waste into a stable glass product. During the last four years, PNL has devel- oped the joule-heated ceramic melter as a major component of this process. A prime step toward developing a glass melter capable of hot-cell operation has been the construction, start-up, and operation of the full-scale liquid-fed ceramic melter (LFCM), shown in Figure 1. This report presents the general component design of the LFCM melter. 


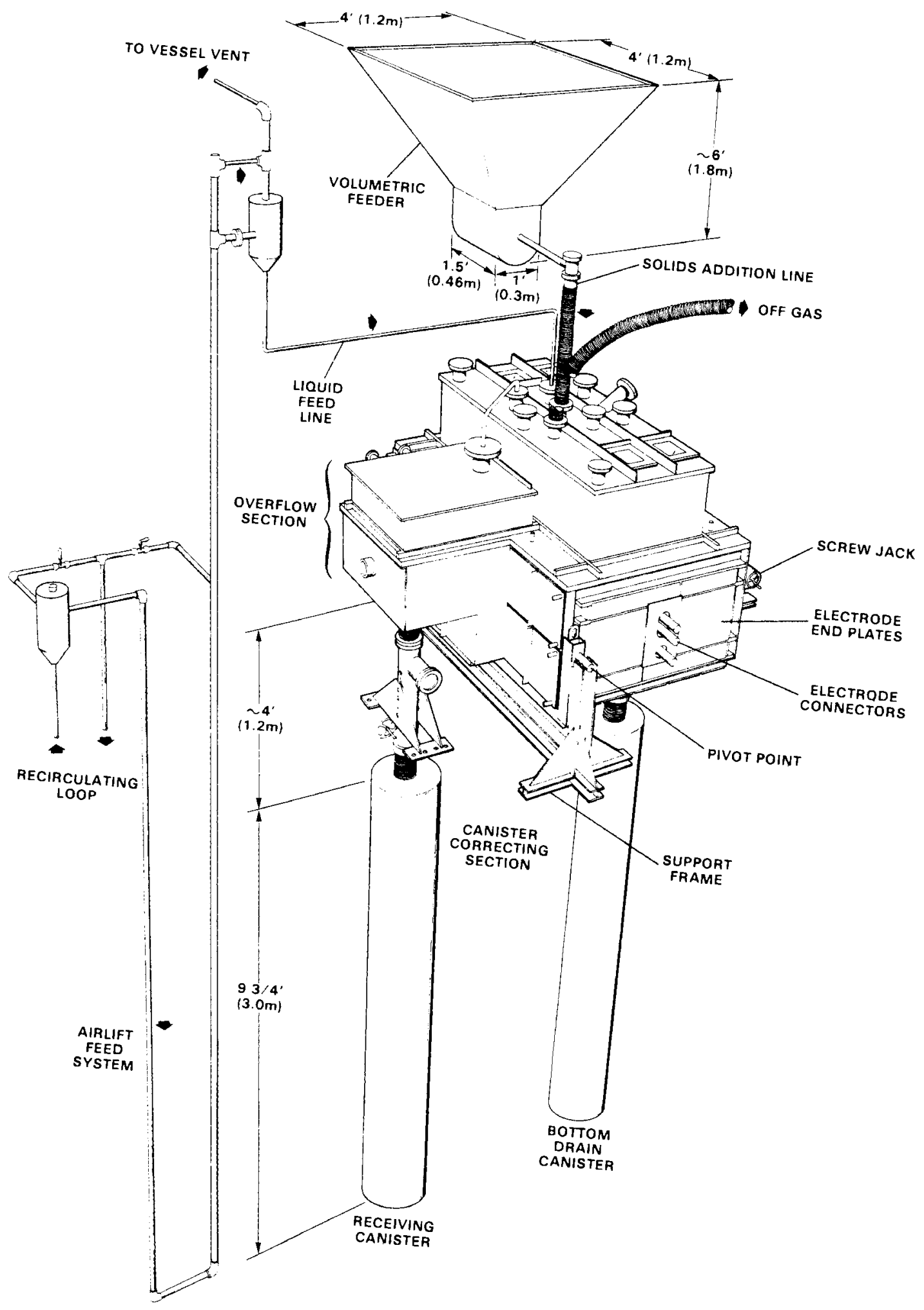

FIGURE 1. Liquid-Fed Ceramic Melter 
The basic nuclear waste solidification process drys and oxidizes liquid waste to a solid form called calcine and melts it with glass additives to produce a stable glass product. The LFCM's smaller predecessor, the Engineering-Scaled Ceramic Melter (ESCM), demonstrated that liquid waste could be directly converted to glass in the melter without precalcination. The LFCM was then constructed so that the process feasibility could be demonstrated with simulated nonradioactive waste at a larger scale. Data could be acquired on capacities, glass quality, and volatile species control.

The LFCM was designed to process simulated liquid waste at a rate of $75 \mathrm{l} / \mathrm{hr}$, although even greater rates have been demonstrated. The melter was also designed to maintain the capability of calcine feeding, a more developed process. Feed rates for calcine feeding have been demonstrated which have produced as much as $140 \mathrm{~kg}$ of glass per hour (3.4 tonne/day).

To date, the LFCM has been and will continue to be demonstrated with simulated defense wastes in both short- and longterm runs. Because of the wide variation in the types of high-level waste and resulting glass compositions for defense wastes, the melter had to be designed to accomodate all these compositions. The LFCM is used to determine the quality of the vitrified glass produced by the melter on the basis of homogeneity, devitrification, leach rate, and the extent of cracking of the glass. Thus far, we have found that these properties can be greatly controlled by process adjustments and/or glass additive compositional changes. The melter is also being used to determine, qualitatively and quantitatively, the volatile species during operation and idling or during nonproduction periods, which will exist in a vitrification plant when other in-line equipment is down.

Besides being adaptable to both calcine and liquid feeding, the LFCM has many other improvements over the engineeringscaled unit. These improvements, together with the basic design of the LFCM, are described in general in this report. 


\section{DESIGN FEATURES}

The basic operating principle of the LFCM is the same as any commercial glass industry electric melter. Molten glass contained in high-temperature refractory is subjected to an alternating potential between two electrodes. An alternating current is thus conducted between the electrodes by mobile ions in the molten glass. The current produces a heatgenerating effect in the molten glass known as "joule heating." The primary differences between radioactive waste glass melters and industrial glass melters are that the waste melters:

- must be remotely operated and maintained for hot cell operation

- contain gaseous effluents for treatment (operated at a partial vacuum)

- have a long life under continuous operation.

The basic elements that make up the LFCM are the:

- refractory, which contains the molten glass

- electrodes and power system which provide and control the necessary power to sustain melting

- containment box, which contains the refractory and electrode materials and provides effluent isolation and secondary glass containment

- primary drain control system, which allows remote control of glass outflow

- bottom drain, which allows for complete or partial draining of the LFCM

- auxiliary heating systems, which provide heat to areas not attainable through joule heating or conduction
- instrumentation, which records temperature, electrical, cooling flow and other operationa 1 signals

- feed systems

- effluent systems, which treat off gases before release.

\section{REFRACTORY}

The molten glass in the LFCM is contained by high-temperature refractories. The refractories are constructed of two basic layers. First, the glass-contact refractory, which maintains the highest resistance to corrosive attack, contains the molten glass directly. A backup layer of insulating refractory provides higher thermally-insulative properties, yet still maintains good corrosive resistance.

The glass contact refractory, shown in Figures 2 and 3 must be:

- resistant to corrosion over long periods of time at operating temperatures $\left(1200^{\circ} \mathrm{C}\right)$

- electrically resistive relative to the molten glass to avoid electrical shorting

- thermally insulative

- resistant to thermal shock.

It is commonly known that high chromia refractories have excellent resistance to corrosion. However, chromia refractories also have high electrically conductive properties. For the refractory lining in the LFCM, we chose Monofrax ${ }^{\otimes} \mathrm{K}-3$, which contains about $30 \%$ chromia and $60 \%$ alumina. Thus far, the refractory has shown the same excellent corrosion resistance as the higher chrome containing Monofrax $E$, used in the ESCM. However, the K-3 does not pose a shorting problem because of higher electrical resistivity.

${ }^{\circledR}$ Monofrax is a registered trademark of the Carborundum Co., Falconer, NY. 


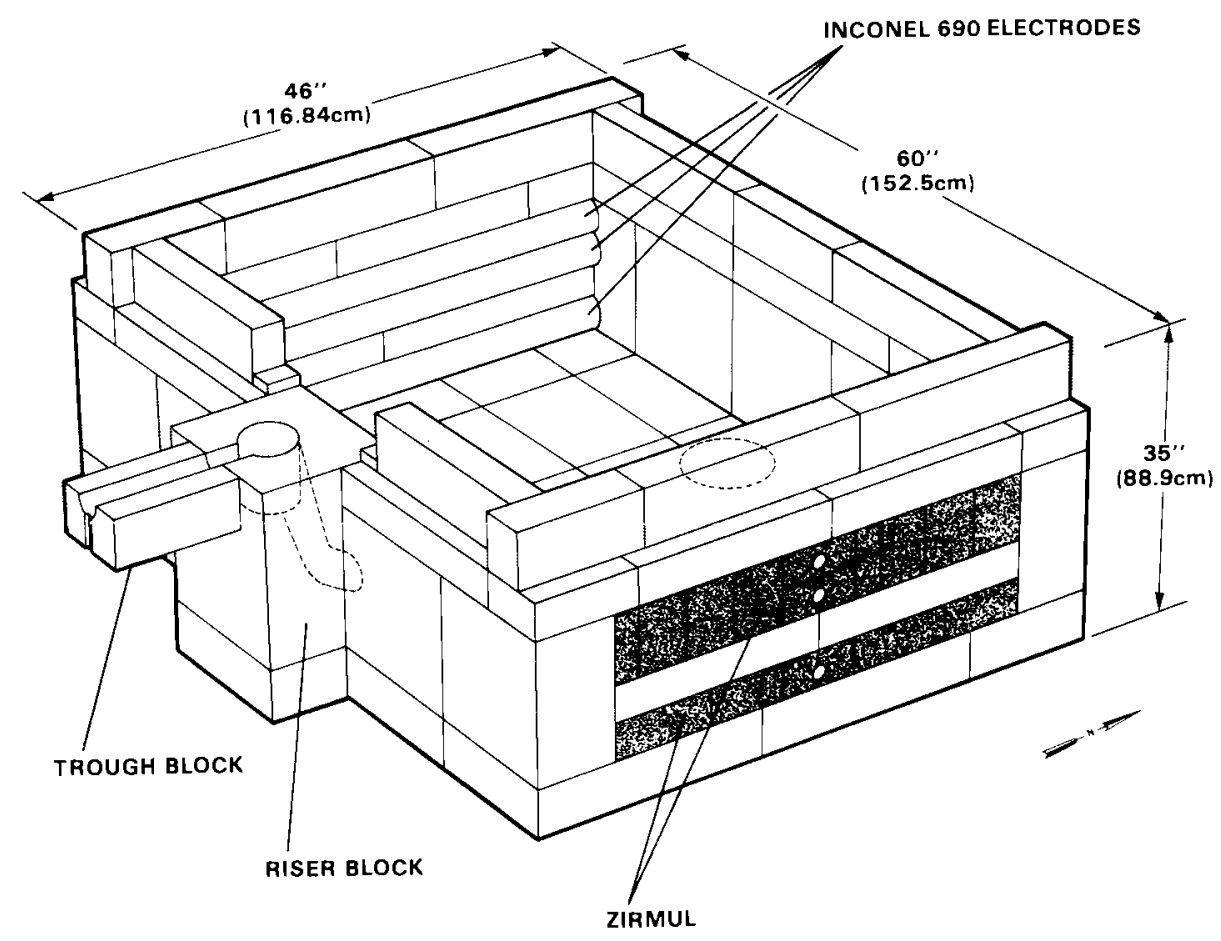

FIGURE 2. Glass Contact Refractory, Southeast View

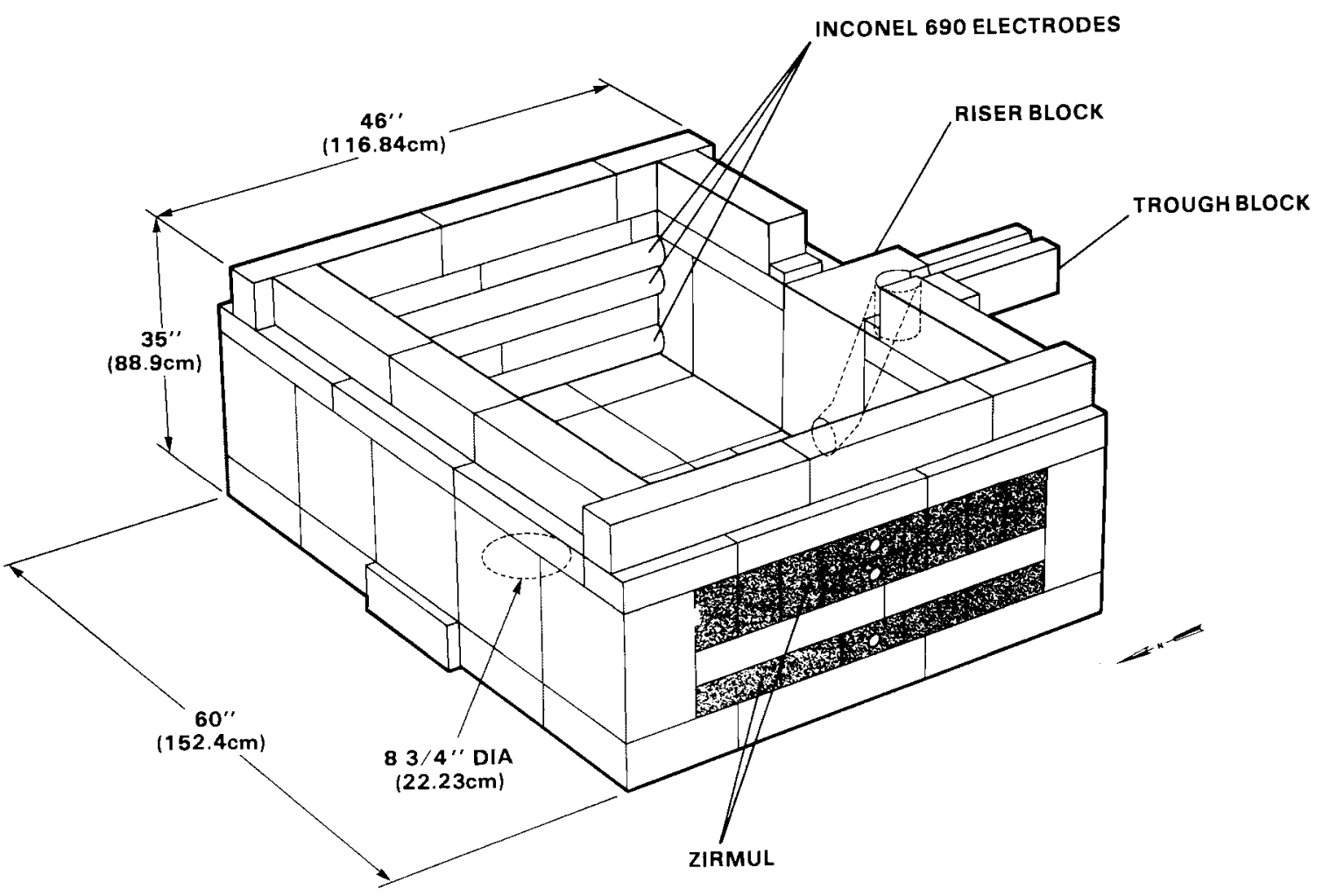

FIGURE 3. Glass Contact Refractory, Northwest View 
Because the $k-3$ is fused-cast, it is very dense and has a fairly high thermal conductivity relative to other refractory products. Therefore, the walls are backed with 3 in. of Alfrax $\left.{ }^{(}\right)$castable refractory (see Figure 4). The floor is insulated with a dense $Z$ irmu ${ }^{\circledR}$ brick, which has better insulative properties than $\mathrm{K}-3$ but still maintains good resistance to molten glass attack. The floor and walls are surrounded by sheets of mica for added electrical protection. Also, 1/2-in.thick, crushable fiberboard was placed between the walls and containment box to accommodate the thermal expansion of the refractory during heatup.

\section{ELECTRODES AND POWER SYSTEM}

Because of the good corrosion resistance already experienced in the ESCM electrode material, Incone $1^{\circledR} 690$ was chosen for the LFCM unit as well. The electrodes, which were machined out of 5-in.-dia Inconel ingot, are imbedded in the opposing electrode walls. For additional control of glass tank temperatures, the electrodes are arranged in a dual electrode system consisting of an upper and lower set of electrodes, as shown in Figure 5 .

The upper electrodes receive the ir power from a multitopped, 250 KVA single-phase transformer. The power can be controlled by a manual constant current or constant power signal feedback loop. Since electrical resistivity of glass decreases with temperature, constant current control offers a desirable self-regulating feature, because the voltage, and thus power, will decrease as the temperature rises. The electrodes can also be controlled by constant temperature, which is read by an internal thermocouple in the electrodes or an infrared optical pyrometer. Thus far, however, stability and reliability have impeded this type of control. The lower electrodes can either be controlled manually or by a ratio of the current feedback signal from the upper electrodes. The actual power to the electrodes is regulated by silicon controlled rectifiers (SCRs), which allow only a certain phase angle of the voltage wave form supplied to each set of electrodes to pass. Figure 6 shows the overall power system component schematic.

\section{CONTAINMENT BOX}

To contain gaseous effluents generated during the vitrification process, an airtight box encompasses the entire ceramic melter. This is illustrated in Figures 7 and 8. The construction material for the LFCM container is 304 stainless steel and Incone 1601.

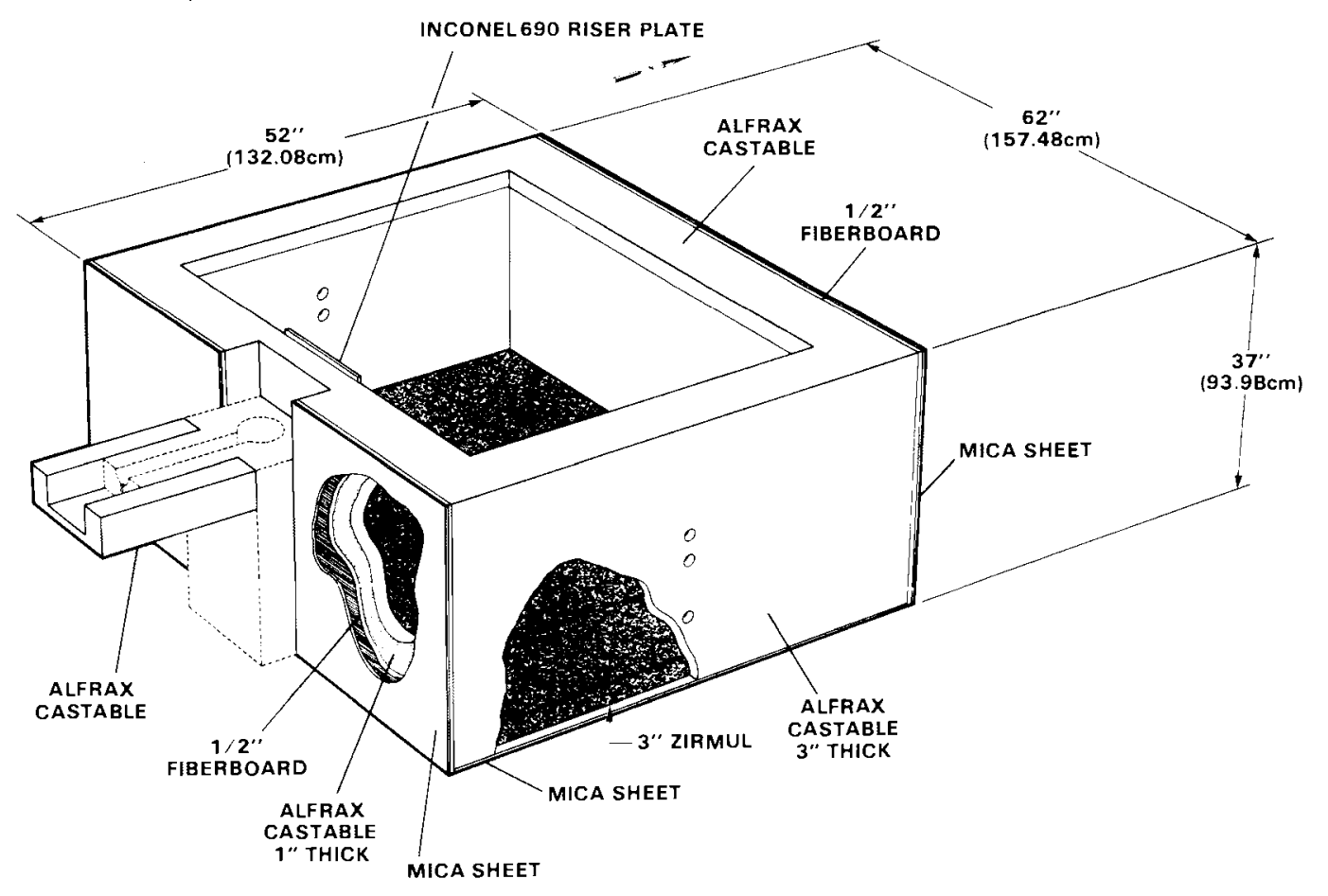

FIGURE 4. Backup and Insulating Refractories

(ब) Alfrax is a registered trademark of the Carborundum Co., Falconer, NY.

Zirmul is a registered trademark of the Charles Tayler Sons Co., Cincinatti, $\mathrm{OH}$.

Inconel is a registered trademark of the International Nickel Co., Huntington, WV. 


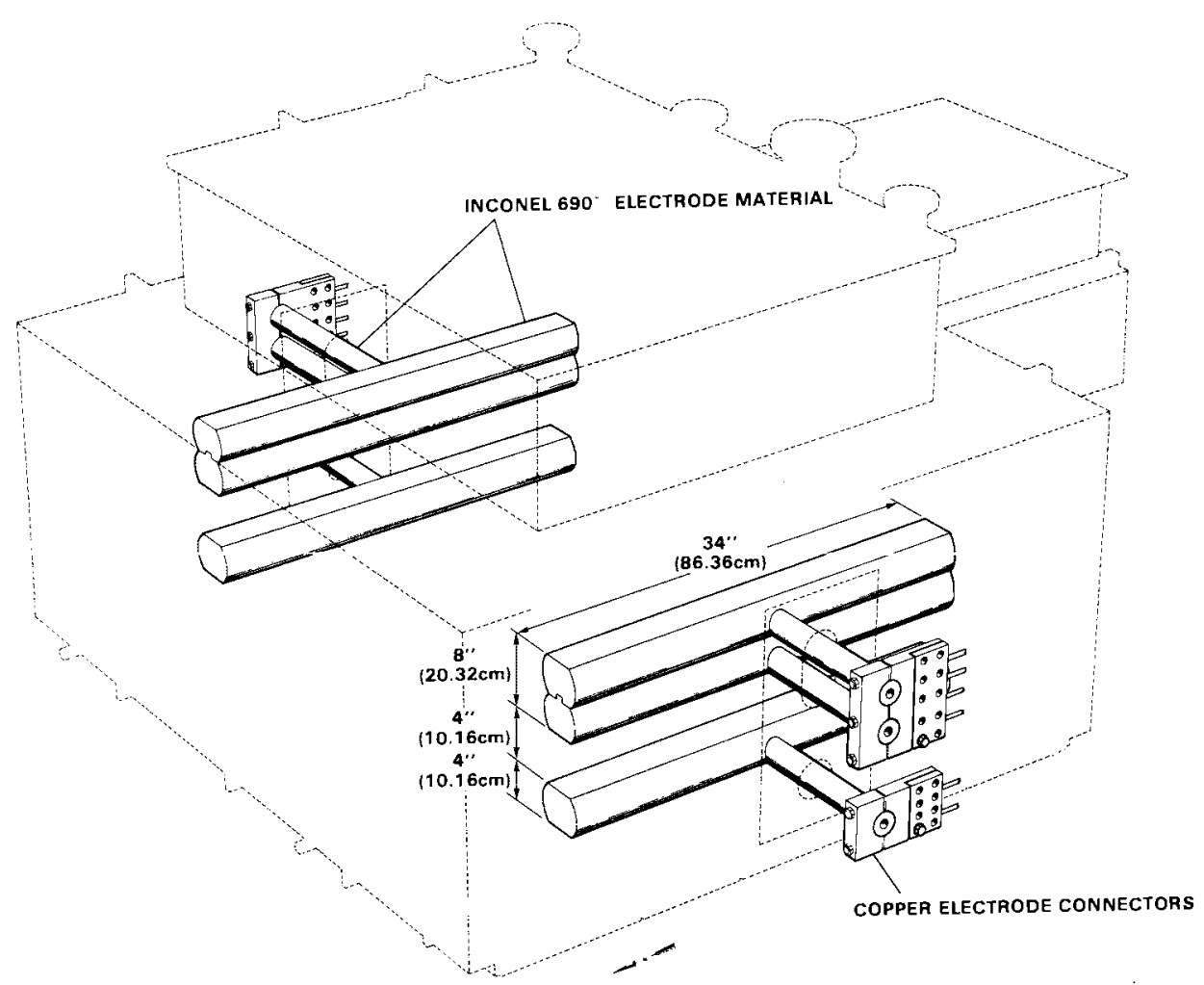

FIGURE 5. Electrode Arrangement

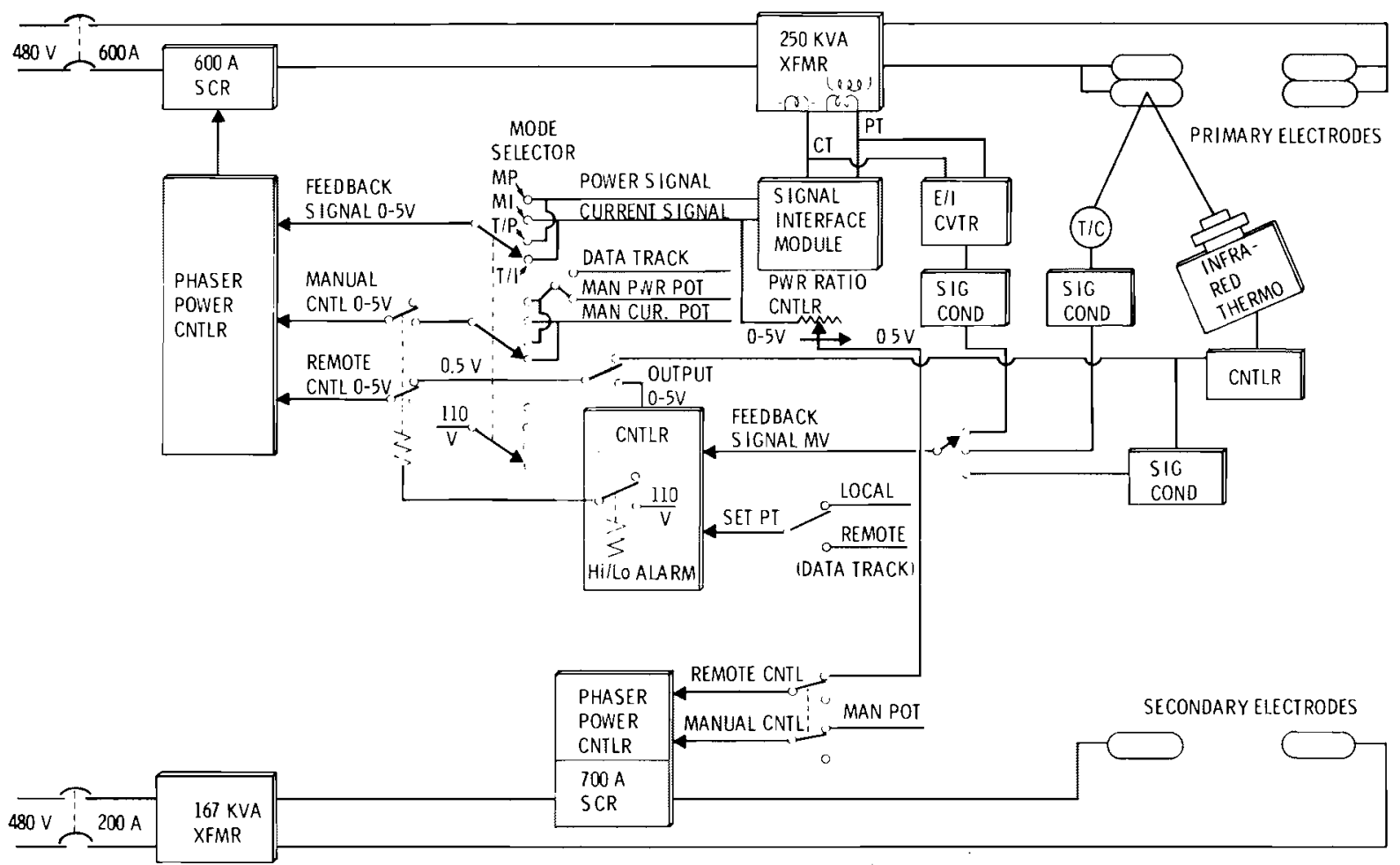

FIGURE 6. Liquid-Fed Melter Electrode Power Control Systems 


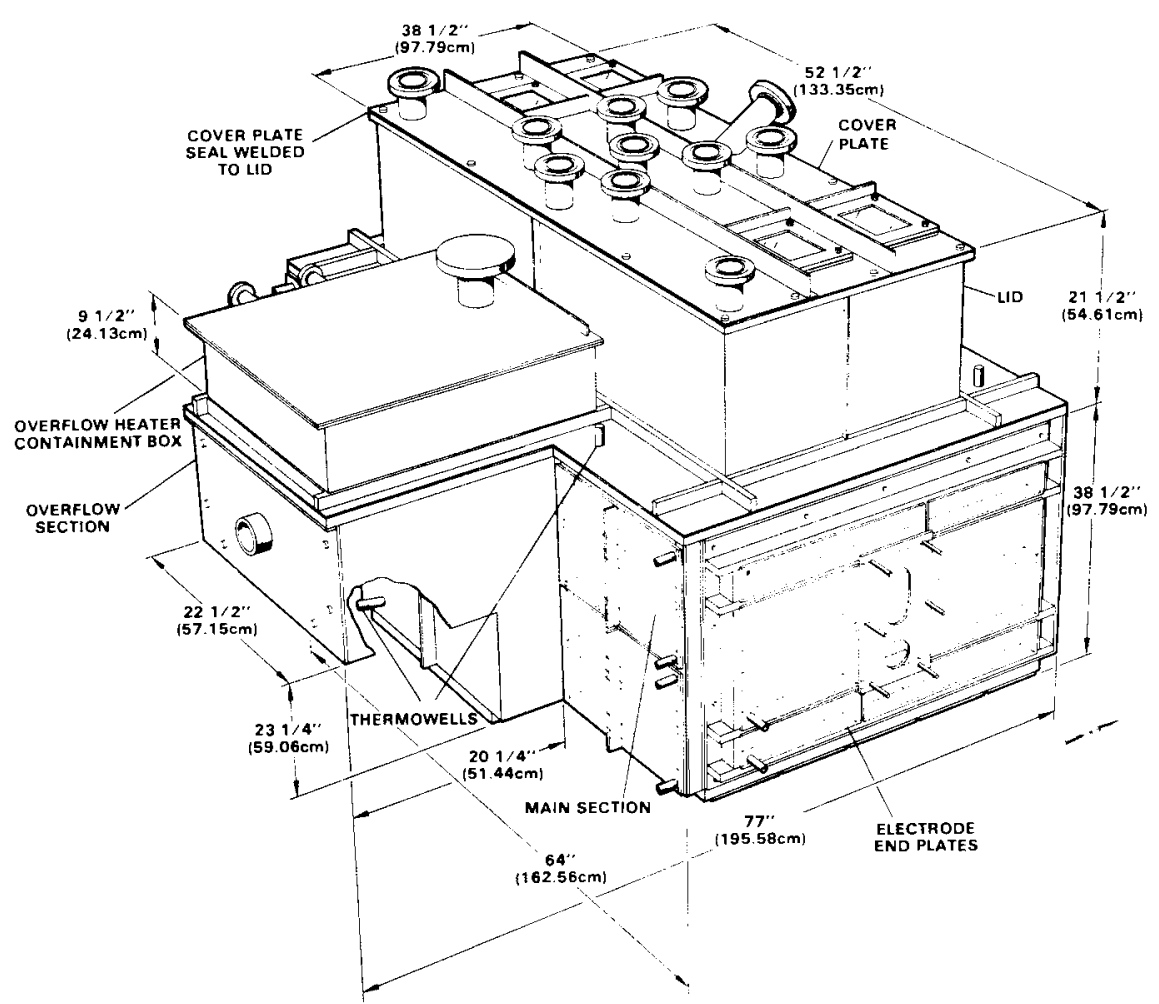

FIGURE 7. Containment Box, Southeast View (a)

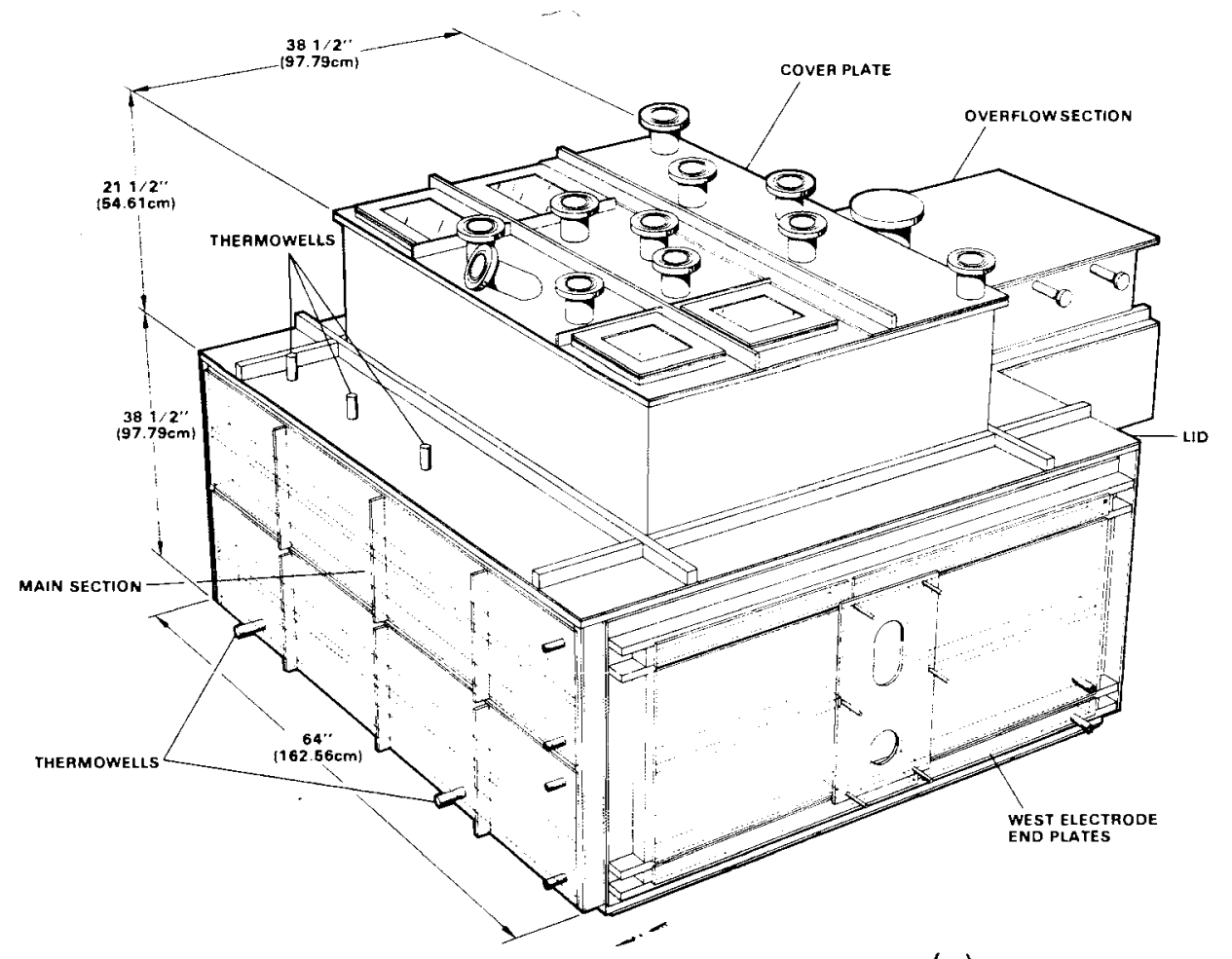

FIGURE 8. Containment Box, Northwest View $(a)$

(a) Constructed of $304 \mathrm{~L}$ stainless stee 1 , unless otherwise specified (lid and cover plate of Inconel 601) 
The lower part of the shell, which contains the refractory components, is lined with cooling baffles. Each of these zones can be controlled independently with either water, steam, or air as the cooling fluid. Aside from keeping the refractories cool, the cooling zone freezes the glass as it approaches the outer wall and acts as a second barrier for preventing glass leakage through a potential crack in the refractory.

The upper section of the melter container, called the lid, provides a head space for gas de-entrainment of dust or aerosol vapors. The lid is surrounded by plate heaters, which can be used for melting builtup material that accumulates during liquid feeding. The lid heaters are controlled manually, automatically by temperature control, or programmatically for heatup and cooldown. The cover plate of the lid has various access ports for feeding, viewing, and acquiring data. The entire lid is attached by a gasket to the main section of the melter box with an asbestos rope. Because of the high tem- perature degradation of asbestos, the melter developed high air inleakage at the cover plate gasket. Therefore, the cover plate was welded to the lid as a single piece. At the gasket to the melter box, the asbestos seal has maintained low enough temperatures to provide a reliable vacuum seal.

\section{PRIMARY DRAIN CONTROL}

During operation, the glass flows from the bottom of the melter through a riser block, over a trough, and into a receiving canister. The glass drainage is controlled by a tilting mechanism, shown in Figure 9. This tilt mechanism operates much the same way as a tea kettle. When the screw jack is raised or lowered, the melter tilts about the pivot point, allowing the glass to drain. Molten glass falls from a pouring spout made of Inconel 690 through an airtight downpipe into the canister below. More than $100 \mathrm{~kg}$ of glass may be drained with $\sim 2^{\circ}$ tilt angle with this melter.

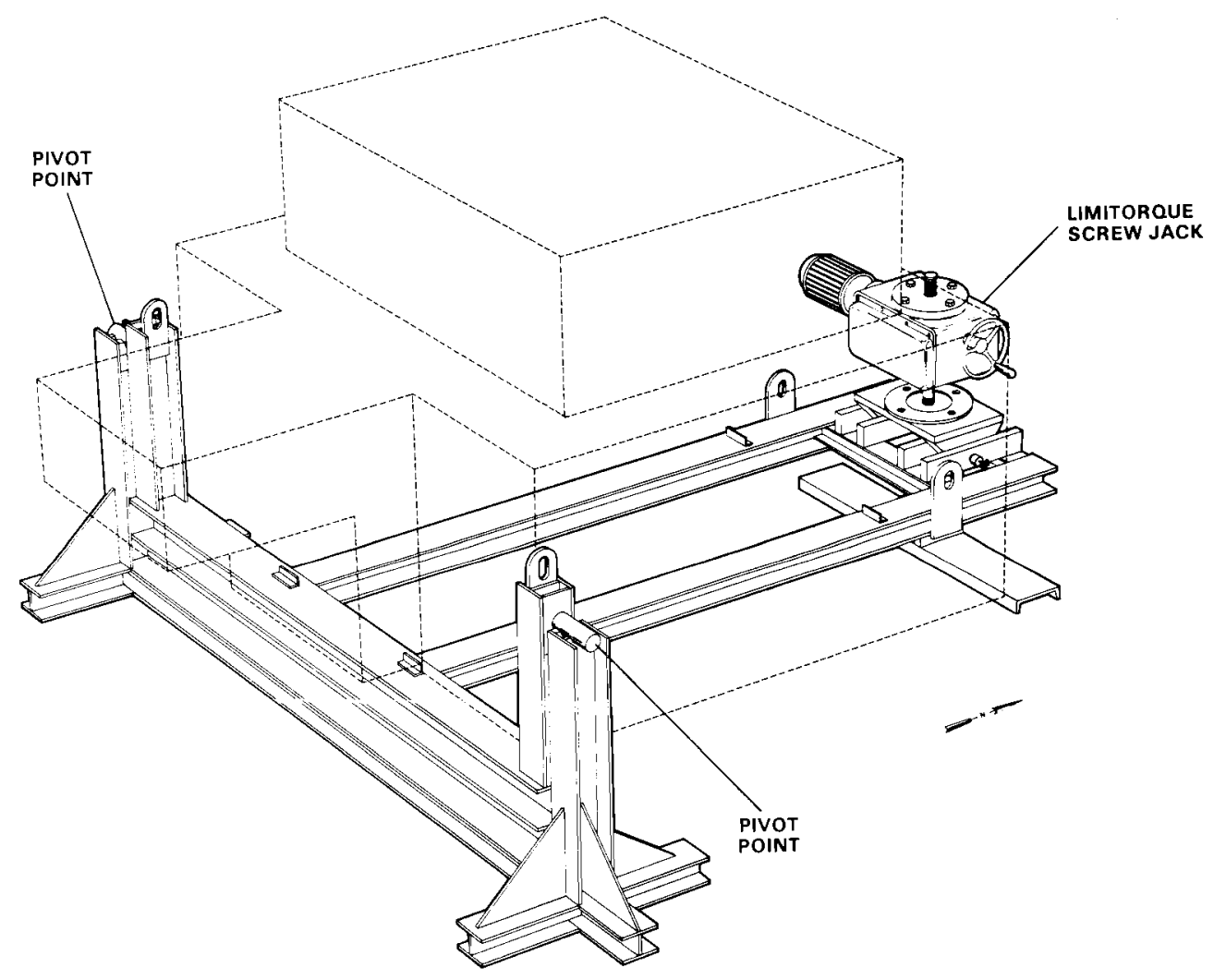

FIGURE 9. Screw Jack and Tilting Cradle 
The overflow section must be heated externally so that the glass will remain fluid enough for pouring. Originally the LFCM utilized three separately-controlled zones of Thermcrafte resistance plate heaters for this purpose. However, inadequate temperatures for the more viscous glasses and operational failure at higher temperatures required a modification. The plate heaters were replaced with three zones of silicon carbide heaters. Each of these zones is controlled independently, either manually or by temperature control. The riser block also has two more zones of plate heaters, which are located outside the containment box.

\section{BOTTOM DRAIN}

A bottom drain was incorporated into the design of the LFCM as an auxiliary drain system and as a method of completely re- moving the glass from the melter for shutdown purposes. For hot cell use, the drain must operate remotely. This type of technology is not available in the commercial glass industry. A schematic of the bottom drain, known as the freeze valve, is shown in Figure 10.

The freeze valve is an annulus $3 / 16-$ in. wide. The annulus is provided with cooling jackets on both the internal-external sides and is also supplied with a heat source. When not in operation, there is a frozen glass plug in the annulus, preventing any glass from flowing. When glass drainage is desired, the cooling is turned off and heat is applied. This will thaw the frozen glass plug and allow the glass to drain. Glass drainage can be controlled and stopped if a cooling fluid is introduced in the cooling jacket. This fluid can be water, steam, or air. At the

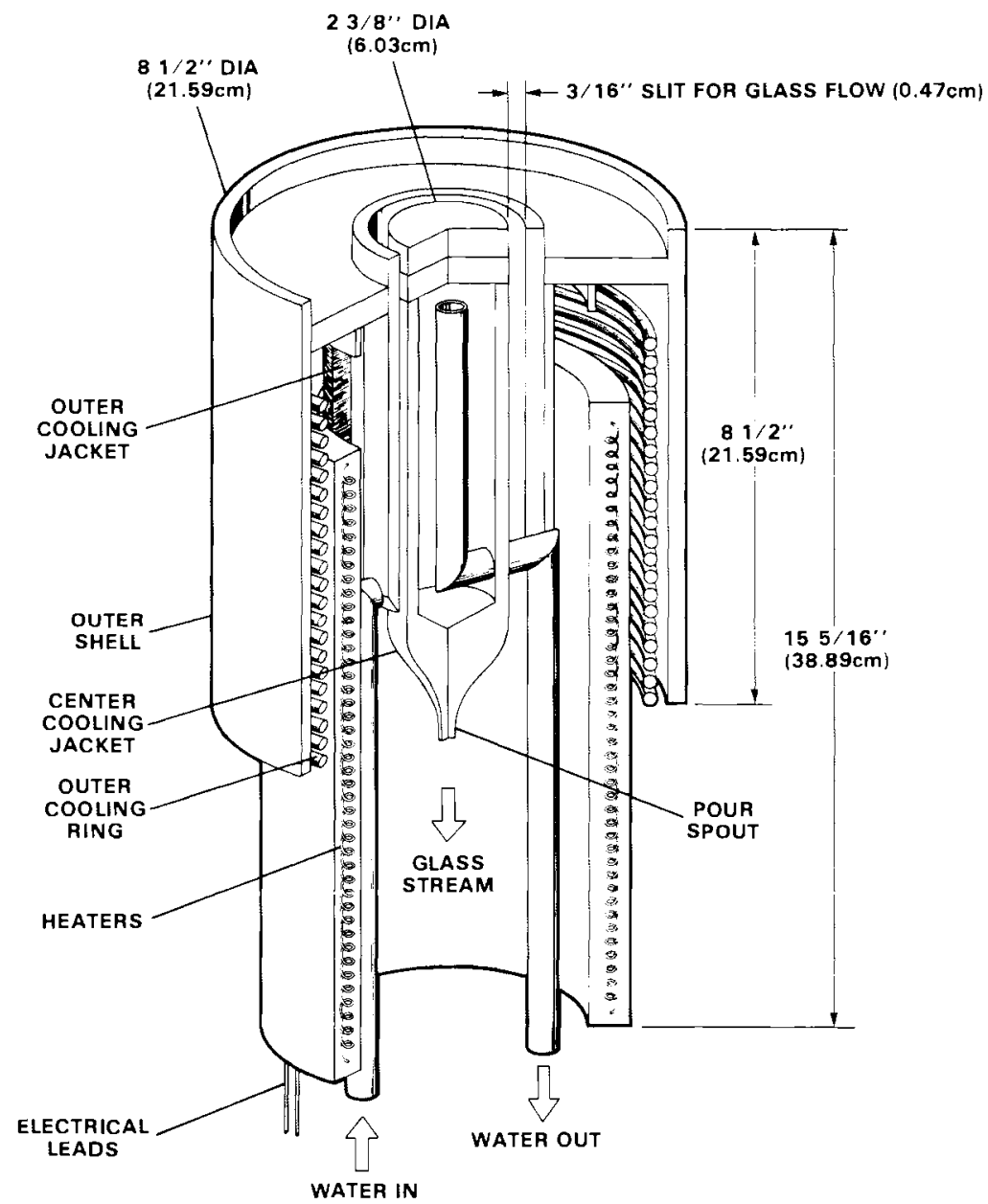

FIGURE 10. Bottom Drain

\footnotetext{
$\overline{(B)}$ Thermeraft is a registered trademark for Thermcraft, Inc., Winston-Salem, NC.
} 
time of this writing, this drain has not yet been demonstrated in the LFCM but has been successfully demonstrated in a previous melter.

\section{AUXILIARY HEATING SYSTEMS}

As already explained, some sections of the LFCM require heat sources in addition to the heat supplied by the power electrodes. The heaters are either ceramic plate heaters with resistance heating wire as the heating element or silicon carbide resistance heaters. Their locations and type are shown in Figure 11 and are identified below:

- Overflow heaters, Zones I, II, and IV

- Riser block heaters, Zones III and V

- Cover plate heaters

- Bottom drain heaters.

\section{INSTRUMENTATION}

The LFCM has been constructed with full instrumentation for maximum data acquisi- tion. Temperatures are continually monitored and recorded for the electrodes, various locations within refractory floor and walls, amid the auxiliary heaters in the overflow, on the lid, and the riser section. Thermocouples are also located in the bottom drain and on the receiving canisters. Cooling flow to the various sections of the melter is also monitored for temperature and flowrate. In addition, the gross canister weight is continually recorded for monitoring the glass production rates.

\section{FEED SYSTEMS}

Because of the different operating modes of this melter, both liquid and powdered feeding, two feed systems are required. Simulated liquid waste is metered by an air lift from a head tank pot up to an air liquid disengagement chamber. From that chamber, the liquid flows by gravity to the melter, as shown in Figure 12. This system is used to demonstrate the use of an airlift for metering liquid waste with slurried glass formers. During calcine feeding, solids are fed through a volumetric feeder through a central flange in

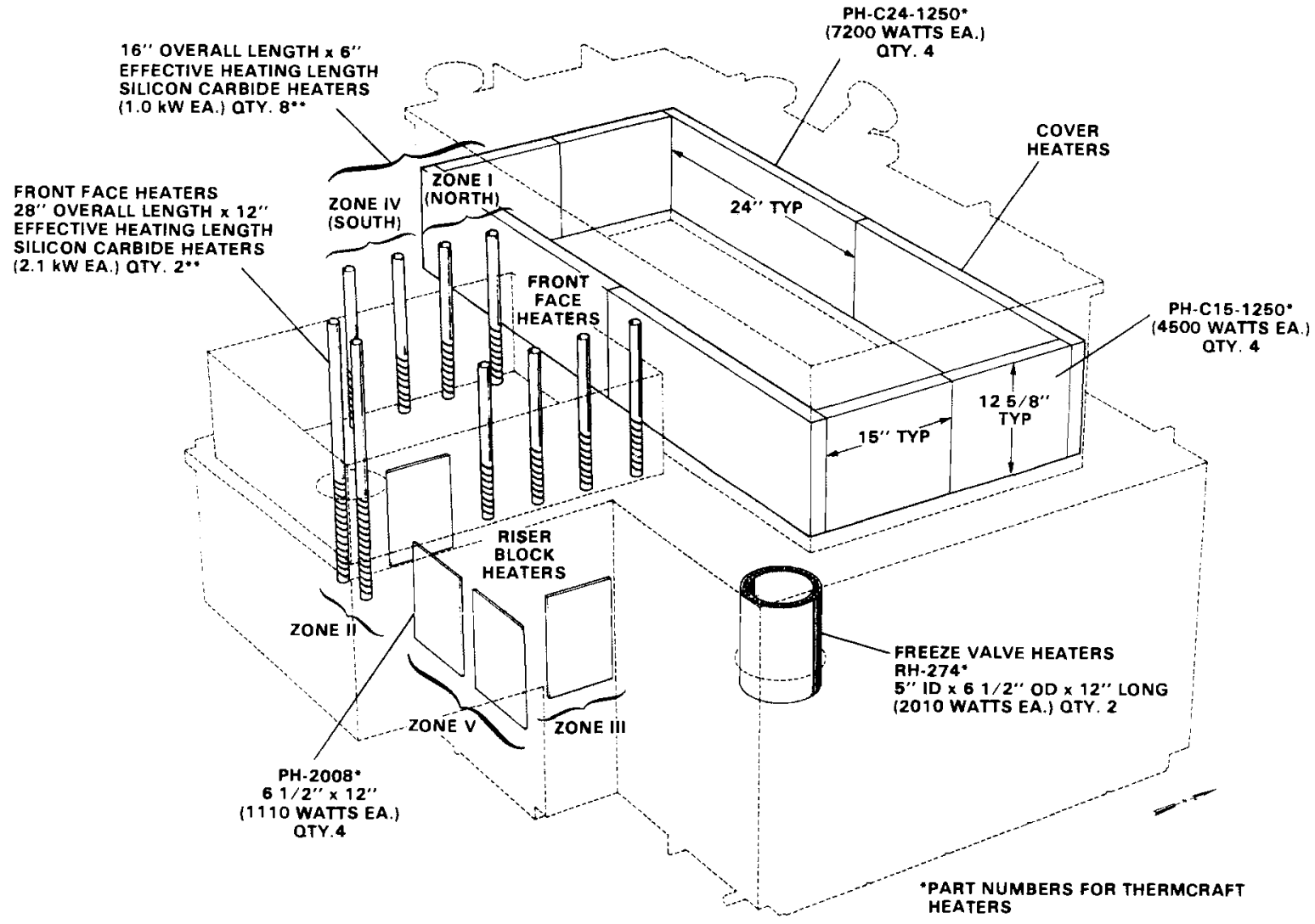

FIGURE 11. Auxiliary Heating Systems 


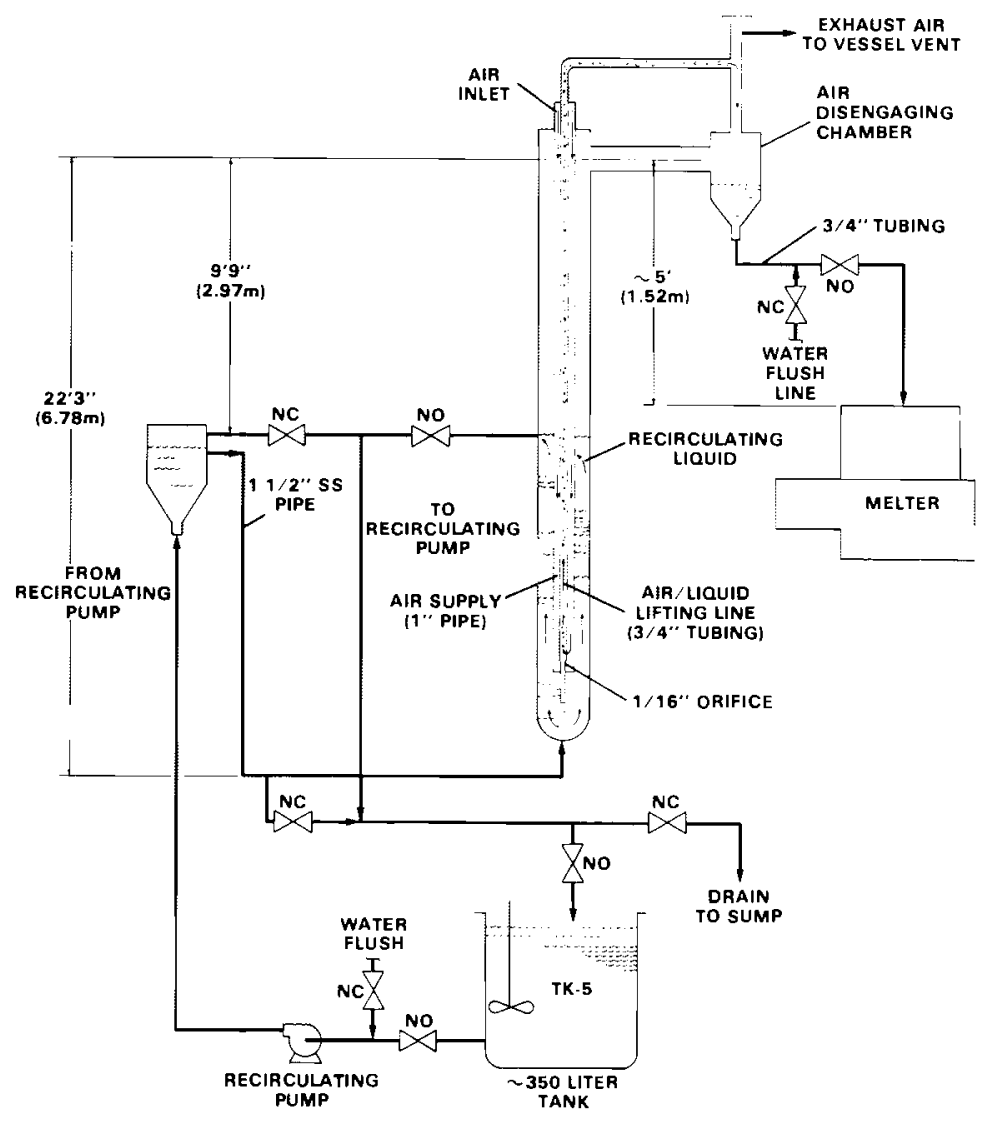

FIGURE 12. Liquid Feed System

the cover plate of the melter. During the early tests with the LFCM, solids were introduced near the rear wall of the melter and were distributed over the entire surface with a batch distributor. The batch distributor consisted of a motor-driven shaft with a sweeping arm. The arm distributed the batch more evenly over the surface of the melt. This process was eliminated to reduce the amount of moving parts on the calcine-fed system.

\section{OFF-GAS SYSTEM}

The gases generated from the vitrification process first pass through a HEPA filter for particulate removal and mea- surement, then travel through a condenser, venturi scrubber, and packed-column scrubber for removal of nitrates and other effluents. The noncondensibles are then exhausted through a blower to the atmosphere. Figure 13 shows the off-gas system used for the LFCM and other existing process equipment. Vacuum in the melter is controlled by a valve upstream from the off-gas blower. The melter is also provided with an auxiliary off-gas system which consists of two venturi scrubbers in series followed by a condenser. The melter can also be vented to a process off-gas system, which would handle the load in the event of the primary vacuum system failure. 


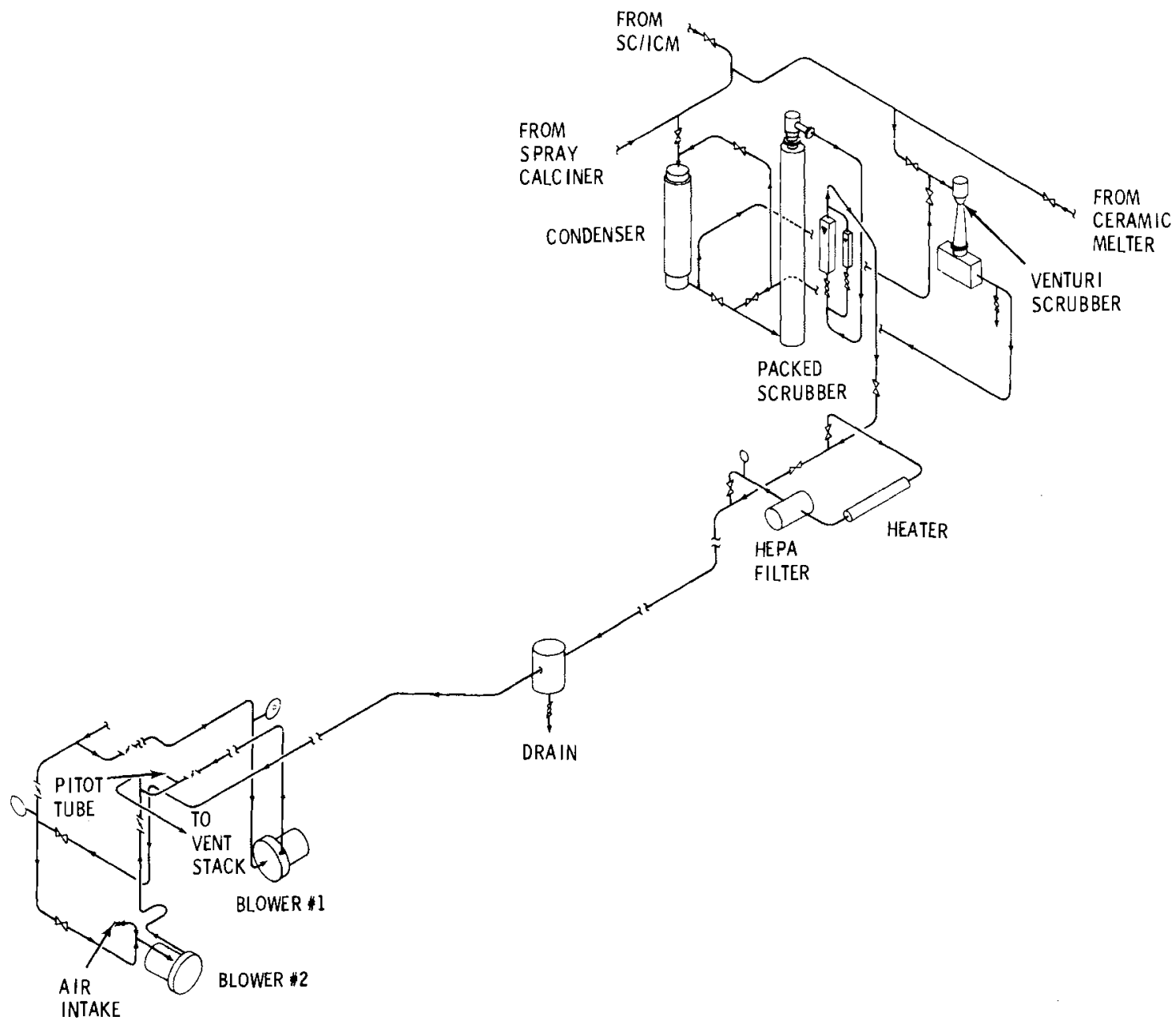

FIGURE 13. Off-Gas Treatment System 


\section{CONCLUSIONS}

In order to solidify high-level nuclear wastes into a glass product, process equipment must be designed to be long-lived, remotely operable, and reliable. The liquid-fed ceramic melter described here meets such requirements for continuous melters. Refractories, electrodes, and other LFCM materials are long-lived; the melter has already been up to operating temperature for more than a year and a half, with a longer life expected. Glass production can be remotely controlled through a tilting cradle arrangement. The LFCM has also proven to be very reliable. Its design has allowed short-and long-term testing with both powder and liquid feeds. These tests have added to our understanding of the nuclear

waste vitrification process using continuous melters. Results of these tests will be explained in upcoming PNL reports. 
No. of

Copies

\section{UNITED STATES}

A. A. Churm

DOE Chicago Patent Division

9800 South Cass Avenue

Argonne, IL 60439

R. E. Cunningham

Deputy Director for Fuels and Materials

Nuclear Regulatory Commission

Silver Springs, MD 20910

W. P. Bishop

Assistant Director for Radioactive Waste Management Branch

NRC Division of Materials and Fuel Cyc le Facility Licensing

Washington, DC 20545

W. G. Belter

DOE Division of Biomedical and Environmental Research

Earth Sciences Branch

Washington, DC 20545

W. A. Brobst

DOE Division of Environmental Control Technology

Washington, DC 20545

W. E. Mott

DOE Division of Environmental Control Technology

Washington, DC 20545

R. B. Chitwood

DOE Division of Nuclear

Power Development

Washington, DC 20545

T. C. Chee

DOE Office of Nuclear Waste

Management

Washington, DC 20545

C. R. Cooley

DOE Office of Nuclear Waste Management

Washington, DC 20545

She ldon Meyer

DOE Office of Nuclear Waste Management

Washington, DC 20545

R. G. Romatowski

DOE Office of Nuclear Waste

Management

Washington, DC 20545
No. of

Copies

C. W. Kuhlman

DOE Office of Nuclear Waste

Management

Washington. DC 20545

C. A. Heath

DOE Office of Nuclear Waste Management

Washington, DC 20545

G. Oerte 1

DOE Office of Nuclear Waste

Management

Washington, DC 20545

A. F. Perge

DOE Office of Nuclear Waste

Management

Washington, DC 20545

D. L. Vieth

DOE Office of Nuclear Waste Management

Washington, DC 20545

R. D. Walton

DOE Office of Nuclear Waste Management

Washington, DC 20545

J. Neff, Program Manager

Department of Energy

Columbus Program Office

$505 \mathrm{King}$ Avenue

Columbus, $\mathrm{OH} 43201$

J. B. Whitsett

DOE Idaho Operations office

P.0. Box 2108

Idaho Falls, ID 83401

J. J. Schreiber

DOE Oak Ridge Operations Office

P.0. Box $X$

Oak Ridge, TN 37830

John Van Cleve

DOE Oak Ridge Operations Office

P.0. Box $X$

Oak Ridge, TN 37830

E. S. Goldberg

DOE Savannah River

Operations Office

P.0. Box A

Aiken, SC 29801 
No. of

Copies

\section{DOE Technical Information Center}

A. P. Roeh, Manager

Allied Chemical Corporation

550 2nd Street

Idaho Falls, ID 83401

J. R. Berreth

Allied Chemical Corporation

550 2nd Street

Idaho Falls, ID 83401

R. A. Brown

Allied Chemical Corporation

550 2nd Street

Idaho Falls, ID 83401

C. A. Hawley

Allied Chemical Corporation

550 2nd Street

Idaho Falls, ID 83401

D. A. Knecht

Allied Chemical Corporation

550 2nd Street

Idaho Falls, ID 83401

Allied Chemical Corporation

(File Copy)

550 2nd Street

Idaho Falls, ID 83401

R. A. Buckham

Allied-General Nuclear Service

P.0. Box 847

Barnwe 11, SC 29812

A. Williams

Allied-General Nuclear Service

P.0. Box 847

Barnwe11, SC 29812

J. L. Jardine

Argonne National Laboratory

9700 South Cass Avenue

Argonne, IL 60439

M. M. Steindler/L. E. Trevorrow

Argonne National Laboratory

9700 South Cass Avenue

Argonne, IL 60439

J. M. Batch

Battelle Memorial Institute

505 King Ave.

Columbus, $\mathrm{OH} 43201$

Wayne Carbiener

Battelle Memorial Institute

505 King Ave.

Columbus, $\mathrm{OH} 43201$
No. of

Copies

J. D. Duguid

Battelle Memorial Institute

$505 \mathrm{King}$ Ave.

Columbus, $\mathrm{OH} 43201$

R. E. Heineman

Battelle Memorial Institute

505 King Ave.

Columbus, $\mathrm{OH} 43201$

J. Kircher

Battelle Memorial Institute

505 King Ave.

Columbus, $\mathrm{OH} 43201$

Don Moak

Battelle Memorial Institute 505 King Ave.

Columbus, $\mathrm{OH} 43201$

Ken Yates

Battelle Memorial Institute 505 King Ave.

Columbus, $\mathrm{OH} 43201$

Brookhaven National Laboratory

Reference Section

Information Division

Upton, NY 11973

M. Steinberg

Brookhaven National Laboratory

Upton, NY 11973

Cumbustion Division

Combustion Engineering, Inc.

Windsor, CT 06095

B. Adams

Corning Glass Works

Technical Staffs Division

Corning, NY 14830

E. Vejvoda, Director

Chemical Operations

Rockwe 11 International

Rocky Flats Plant

P.0. Box 464

Golden, CO 80401

M. D. Boersma

duPont Company, Aiken (DOE)

E. I. duPont DeNemours and Company

Savannah River Laboratory

Aiken, SC 29801

S. D. Harris, Jr.

E. I. duPont DeNemours and Company

Savannah River Laboratory

Aiken, SC 29801 
H. L. Hull

E. I. duPont DeNemours and Company Savannah River Laboratory

Aiken, SC 29801

C. H. Ice

E. I. duPont DeNemours and Company

Savannah River Laboratory

Aiken, SC 29801

Robert Maher

E. I. duPont DeNemours and Company Savannah River Laboratory

Aiken, SC 29801

M. S. Plodinec

E. I. duPont DeNemours and Company Savannah River Laboratory

Aiken, SC 29801

A. S. Jernings

E. I. duFont DeNemours and Company Savarınah River Laboratory

Aiken, SC 29801

Leon Meyers

E. I. duPont DeNemours and Company Savannah River Laboratory

Aiken, SC 29801

P. H. Permar duPont Company, Aiken (DOE)

E. I. duPont DeNemours and Company Savannah River Laboratory

Aiken, SC 29801

H. Henning

Electric Power Research Institute

3412 Hillview Avenue

P.0. Box 10412

Palo Alto, CA 94301

Environmental Protection Agency

Technology Assessment Division (AW-559)

Office of Radiation Programs

Washington, DC 20460

R. G. Barnes

General Electric Company

175 Curtner Avenue (M/C 160)

San Jose, CA 95125

L. H. Brooks

Gulf Energy and Environmental Systems

P.0. Box 81608

San Diego, CA 92138

3 Los Alamos Scientific Laboratory (DOE)

P.0. Box 1663

Los Alamos, NM 87544
C. J. Kershner

Monsanto Research Corporation Mound Laboratory

P.0. Box 32

Miamisburg, OH 45342

John Pomeroy

Technical Secretary

National Academy of Sciences

Committee of Radioactive Waste

Management

National Research Council

2101 Constitution Avenue

Washington, DC 20418

S. D. Barrett

New England Power Company

280 Melrose Street

Providence, Rhode Is land 02901

2 J. P Duckworth

Plant Manager

Nuclear Fuel Services, Inc.

P.0. Box 124

West Valley, NY 14171

J. G. Cline, General Manager

NYS Energy Research and Development

Authority

230 Park Avenue, Rm 2425

New York, NY 10017

2 Oak Ridge National Laboratory (DOE)

Central Research Library

Document Reference Section

P.0. Box $X$

Oak Ridge, TN 37830

E. H. Kobish

Solid State Division

Oak Ridge National Laboratory

Oak Ridge, TN 37830

G. J. McGarthy

Pennsylvania State University

Materials Research Laboratory

University Park, PA 16802

D. R. Anderson

Sand ia Laboratories

Albuquerque, NM 87107

J. K. Johnstone

Sandia Laboratories

Albuquerque, NM 87107

W. Weart

Sandia Laboratories

Albuquerque, NM 87107

J. Sivinshi

Sandia Laboratories

Albuquerque, NM 87107 
J. 0. B lomeke

Union Carbide Corporation (ORNL)

Chemical Technology Division

P.0. Box Y

Oak Ridge, TN 37830

2 D. E. Ferguson

Union Carbide Corporation (ORNL)

Chemical Technology Division

P.O. Box $Y$

Oak Ridge, TN 37830

H. W. Godbee

Union Carbide Corporation (ORNL)

Chemical Technology Division

P.0. Box Y

Oak Ridge, TN 37830

W. C. McClain

Union Carbide Corporation (ORNL)

Chemical Technology Division

P.0. Box $Y$

Oak Ridge, TN 37830

R. A. Beall

U. S. Department of Interior Bureau of Mines

Albany Research Center

$1450 \mathrm{~W}$. Queen Avenue

Albany, OR 97321

D. B. Stewart

U. S. Department of Interior

959 National Center

Geological Survey

Reston, Virginia 22092

R. G. Post

College of Engineering

University of Arizona

Tucson, AZ 85721

S. E. Logan

University of New Mexico

Albuquerque, NM 87131

\section{ONSITE}

5 DOE Richland Operations Office

R. B. Goranson

B. D. Guilbeault

M. J. Shupe

D. J. Squires

M. J. Zamorski

11 Rockwell Hanford Operations
H. Badad
R. A. Deju
R. J. Gimer a

Copies

ONSITE

B. Higley

J. D. Kaser

E. J. Kosiancic

M. J. Kupfer

C. M. Manry

J. H. Roecker

W. W. Schultz

D. D. Wodrich

File copy

3 Exxon Nuclear Company

S. J. Beard

Joint Center for Graduate Study

J. Cooper

2 United Nuclear Industries, Inc.

T. E. Dabrowski

A. E. Engler

Westinghouse Hanford Company

A. G. Blasewitz

72 Battelle-Northwest

T. W. Ambrose

S. M. Barnes

W. J. Bjorklund

H. T. Blair

W. F. Bonner

D. J. Bradley

R. Browns

J. L. Buelt (10)

R. L. Bunnel1

C. C. Chapman (10)

L. A. Chick

T. D. Chikalla

M. 0. Cloninger

R. L. Cox

R. D. Dierks

T. Donovan

J. W. Finnigan

A. A. Garrett

W. J. Gray

C. W. Griffin

M. S. Hanson

M. H. Henry

R. Hjelm

O. F. Hill

J. H. Jarrett

Y. B. Katayama

D. E. Knowlton

D. K. Kreid

D. E. Larson

J. M. Lukacs 
No. of

Copies

ONSITE

J. L. McElroy (10)

J. S. McPherson (3)

G. B. Mellinger

J. E. Mendel

R. E. Nightingale

D. E. Olesen

C. R. Palmer

A. M. Platt

D. L. Prezbindowski (2)

B. A. Price

S. Quigley

W. A. Ross

J. M. Rusin

D. H. Siemens

S. C. Slate

R. T. Treat

R. P. Turcotte

H. H. Van Tuyl

J. H. Westsik, Jr.

Technical Information (5

Publishing Coordination (2) 
$-$

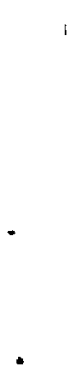

